\title{
COMPETIÇÃO E COOPERAÇÃO: NA PROCURA DO EQUILÍBRIO
}

\author{
DR. HUGO RODOLFO LOVISOLO
}

Doutor em Antropologia Social pela Universidade Federal do Rio de Janeiro (UFRJ)

Professor adjunto da Universidade Estadual do Rio de Janeiro (Rio de Janeiro - Rio de Janeiro - Brasil)

E-mail: lovisolo@globo.com

\section{DR. CARLOS NAZARENO FERREIRA BORGES}

Doutor em Educação Física pela Universidade Gama Filho (UGF), Professor adjunto da Universidade Federal do Espírito Santo, Centro de Estudos em Sociologia das Práticas Corporais e Estudos Olímpicos (Cespceo/CEFD/UFES) (Vitória - Espírito Santo - Brasil)

E-mail: carlos.nazareno@pq.cnpq.br

\section{MS. IGOR BARBARIOLI MUNIZ}

Mestre em Educação Física pela Universidade Federal do Espírito Santo (UFES),

Centro de Estudos em Sociologia das Práticas Corporais e Estudos Olímpicos (Cespceo/CEFD/UFES)

(Vitória - Espírito Santo - Brasil)

E-mail: igorbmuniz@yahoo.com.br

\section{RESUMO}

O artigo analisa o conteúdo das mensagens que coloca a proposta dos jogos cooperativos como superior aos jogos competitivos, especialmente quando se propõe uma educação transformadora em relação aos valores sociais humanos. Para tanto, foram analisadas as principais ideias dos autores que têm se dedicado ao estudo dos jogos cooperativos. De uma forma geral, os argumentos utilizados enfatizam os valores da cooperação em detrimento da competição, responsabilizando os jogos competitivos pela disseminação de contra valores educativos. Como resultado, temos afirmações retóricas, sem evidências ou fundamentações teóricas consistentes, uma tentativa forçada dos autores de legitimar os jogos cooperativos na educação pretendida e de mostrar a sua vantagem sobre os jogos competitivos.

PALAVRAS-CHAVE: Retórica; jogos cooperativos; jogos competitivos. 
Nas últimas décadas se multiplicaram, no campo da educação física, propostas cujo valor orientador ou objetivo central é a transformação da sociedade mediante a transformação dos indivíduos (crianças e adolescentes), quer seja no contexto da escola, quer seja no contexto dos projetos ditos alternativos. De modo geral, as propostas adquiriram a retórica já presente no campo da educação, que ataca dois adversários tidos como fundamentais: a) o sistema capitalista competitivo e seus principais ideólogos - os neoliberais, e; b) o campo difuso e mal definido da educação dita tradicional. Lembremos, parafraseando a Charlot,' que para insultar um pedagogo é suficiente qualificá-lo como "tradicional". Agregaríamos que "neoliberal" é um insulto não menos poderoso. Todavia, faz-se necessário apontar que os neoliberais ou liberais estão divididos em matéria educacional. Talvez a minoria apóie o ensino tradicional e parte deles podem até compartilhar as críticas à educação tradicional, e aspirem por propostas inovadoras ou transformadoras em termos individuais que favoreçam a liberdade e a realização pessoal no contexto geral das mudanças da sociedade. A retórica intransigente não distingue e engloba, criando estereótipos para atingir seus objetivos críticos. Não raro, desliza-se da dialética para a publicidade. Devemos exercitar a cautela para não cair em suas armadilhas que, se excitam a emoção, negligenciam a argumentação sólida e a construção de alternativas.

Uma característica, partilhada pelas propostas em pauta, é que parecem confiar excessivamente no poder transformador (ou conservador, como no caso das ditas "teorias da reprodução") da educação e, para manter tal esperança, negam as evidências mais corriqueiras. Outra característica, embora menos importante, é que a retórica em uso apresenta afirmações óbvias. Um exemplo é bater sobre a tecla de que as reformas neoliberais não transformam a sociedade de modo revolucionário nem na direção de um sistema "não capitalista". É evidente que nenhum neoliberal defendeu a ideia de que sua crítica ao planejamento centralizado e em favor do mercado significava um caminho para um regime menos individualista, competitivo, capitalista e mais coletivista. Quando muito, os liberais ou neoliberais pretenderam revitalizar o capitalismo competitivo. Defensores do desenvolvimento como liberdade, como é o caso de Sen (2000), focam o papel de protagonista do Estado na criação das condições de realizações sem diminuir a importância do mercado, e realizam indicações sobre os caminhos a serem seguidos. Decorre do abuso dos estereótipos que a crítica seja apenas retórica no sentido pejorativo do

1. Professor emérito da Universidade de Paris e professor visitante no PPGE da UFSE; Doutor e Livre docente em Ciências da Educação. Um texto específico sobre a afirmação realizada pode ser encontrado em Charlot (2005). 
termo. A obviedade é usada para convencer o leitor. Acreditamos que entre, por um lado, endeusar o mercado e eliminar o Estado e, por outro, demonizar o mercado e endeusar o Estado, existe um caminho intermediário que proporia, da mesma forma que nas propostas de desenvolvimento como liberdade, de Sen (2000), reconhecer a importância da competição e da cooperação na educação física.

A primeira característica mencionada, a Fé transformadora, parece eliminar evidências que podem ser facilmente constatáveis. As primeiras lutas e revoluções socialistas emergiram em países cujos sistemas educacionais podem ser caracterizados de "tradicionais", "reprodutores" e "conservadores". No plano dos indivíduos, figuras díspares como Marx, Lenin, Hitler, Mussolini, Churchill, Stalin, De Gaulle, Gandhi, Castro e Guevara, para citar apenas alguns, estudaram e se formaram em escolas tradicionais. Suas notáveis diferenças de orientação ideológica e no plano do agir político não podem ser explicadas a partir das influências, mais ou menos gerais e uniformes, que implica a educação tradicional. Se tentássemos explicá-las, teríamos que postular um sistema complexo de interação onde se cruzam múltiplas influências, ou reconhecer que a dita educação tradicional talvez estivesse mais interessada em desenvolver a ação de pensar que em gerar a adesão a um tipo de pensamento específico. Não poucas vezes, lembramos como bons professores aqueles que nos instigaram a pensar. A tentativa de gerar a adesão a um pensamento específico parece ser o caso das educações transformadoras e anticapitalistas que, de forma recorrente, porém não única, apóiam-se em um marxismo popular.

Todavia, melhorar o mundo melhorando a educação, seja o que for que isto signifique, não é uma tentativa descabelada. A educação é um dos recursos que temos para essa tarefa coletiva e, portanto, não deve ser descartada, nem reduzida em importância. Entretanto, fazer isso com uma retórica baseada em falsas esperanças, absolutizando quer o poder transformador, quer sua força conservadora, e que desconhece a complexidade das interações sociais e seus efeitos por vezes contraditórios, é uma atitude que deveria ser descartada, pois contribui com o fracasso das boas intenções.

Pretendemos, neste artigo, analisar a proposta dos "jogos cooperativos" para salientar a retórica posta em ação e suas limitações diante da compreensão da complexidade do processo educativo em suas interações, com as condições sociais e outros atores que influenciam a formação. A proposta, dito de forma resumida, caracteriza-se pelo seu espírito anticapitalista, por atacar a competição ("exacerbada", qualificativo amplamente utilizado nos textos) e por entender que os jogos cooperativos podem transformar os indivíduos e a sociedade. Especificaremos melhor a proposta ao longo do artigo e realizaremos comentários críticos com o intuito de propiciar uma melhor fundamentação, tanto dos argumentos 
quanto de suas evidências. Digamos que nos situamos como educadores atraídos pela proposta, e que admiramos o esforço de seus pioneiros, mas que solicitamos, e nos solicitamos, a partir das dúvidas, uma elaboração mais rigorosa. Esperamos que nossos comentários e observações contribuam nessa direção.

Nossa atitude crítica, no entanto, não significa uma crítica à utilização dos "jogos cooperativos". Deve ser entendida como crítica à retórica de uma esperança de transformação radical que deveria ser mais bem fundamentada. Observemos que Dawkins (2007), defensor da teoria biológica das determinações do "gene egoísta", reconheceu o valor de educarmos as crianças no altruísmo. ${ }^{2}$ Esta educação, embora não atue modificando o determinante do gene egoísta, poderia funcionar como contrapeso. Embora não saibamos o poder que teria como contrapeso, a educação altruísta ou cooperativa se justifica simplesmente como aposta prudente em função dos recursos que temos. Contrapesar não significa substituir, no caso, a "competição exacerbada", inimiga da transformação e de um mundo mais cooperativo, como pretende a proposta em foco.

Finalmente, o leitor não deve perder de vista que a cooperação pode ser um meio para a competição, como no caso dos jogos coletivos competitivos, e a competição um meio para a cooperação, porque o inimigo externo força a cooperação entre os cidadãos. Diante de uma catástrofe natural podemos cooperar para minimizar seus efeitos, contudo, os participantes podem competir para serem os melhores cooperadores. Então, diante do exposto, vamos aos argumentos de nossas pressuposições e considerações sobre nossas afirmativas.

\section{JOGOS COOPERATIVOS: PROPOSIÇÕES DE TRANSFORMAÇÃO}

A proposta de transformação mediante os jogos cooperativos talvez tenha sua referência fundadora nos importantes trabalhos analíticos e nas experiências de Terry Orlick. ${ }^{3}$ Uma referência significativa de sua elaboração é a utilização da história e antropologia para extrair exemplos de utilização dos jogos, na antiguidade e entre os povos primitivos, que funcionam como evidências de sua importância. A partir do material antropológico, Orlick ( 1989 ) menciona indícios da existência de sociedades e comunidades primitivas fundadas na cooperação, como os arapesh e os tangu (Nova Guiné), os bathonga e os tasaday (África), os inuit (Alaska), os aborígenes (Austrália), e os índios norte-americanos, entre outros grupos sociais.

2. Ver Dawkins (1979).

3. Canadense, doutor em psicologia, docente e pesquisador da Universidade de Ottawa, tem sido o pesquisador de maior referência quando o assunto é Jogo Cooperativo. 
Muitos desses povos teriam vivido cooperativamente através da dança, dos rituais e das atividades de subsistência, como a caça, a pesca e a agricultura (ORLICK, 1989). Sem entrar na discussão sobre o valor de suas observações, convém lembrar que muitos povos primitivos foram guerreiros e competitivos, talvez em quantidade maior que os cooperativos. Dos contra exemplos não deve ser deduzida nenhuma conclusão sobre natureza humana como real ou modelo (cooperativo ou competitivo). Os exemplos a favor de um ou outro padrão organizativo apenas ressaltam a diversidade cultural e as possibilidades do agir humano, sem implicar a adoção dogmática de algum deles; ou talvez nos impulsionem na direção de conservar e articular os princípios contrapostos.

As pesquisas de Orlick (1989) sobre os jogos cooperativos foram pioneiras no campo da intervenção pedagógica. Orlick (1989) destaca também os estudos de Ted Lentz e de Morton Deutsch como iniciadores ou fundadores, da área da educação de comportamentos cooperativos, através de jogos cooperativos. $\bigcirc$ autor desenvolveu um programa sistematizado de jogos cooperativos de dezoito semanas com crianças do jardim-de-infância. Duas classes foram submetidas aos jogos cooperativos, enquanto outras duas aos jogos tradicionais, embora não seja explicado o significado dos últimos. Observações criteriosas do comportamento dos alunos foram feitas, tanto antes como depois da realização do programa, as quais, segundo Orlick ( 1989), possibilitaram a percepção de mudanças comportamentais significativas durante e ao final do programa com jogos cooperativos. De acordo com o autor, as turmas expostas somente aos jogos tradicionais não apresentaram nenhuma ação cooperativa durante a atividade, muito pelo contrário, apenas se comportaram de maneira egocêntrica, usaram palavreados hostis, e eram cruéis umas com as outras. Já as turmas expostas aos jogos cooperativos, cooperaram tanto durante os jogos como em outros momentos fora do horário de aula. Ainda segundo o autor, as crianças perceberam por elas mesmas a importância de cooperar e ser solidário com o outro. Pensamos que talvez as crianças apenas estivessem jogando o jogo proposto, pois, na pesquisa, não se estabelece a permanência das condutas cooperativas adquiridas. Em outros termos, a competição entre as crianças podia ser pela medalha do "mais cooperativo" ou, mais simplesmente, para satisfazer aos proponentes. $\bigcirc$ ponto é que não pode ser suposta uma relação determinística entre jogar a "isso", competição e cooperação, e ser "isso".

A obra de Orlick, "Winning through cooperation", publicada originalmente em 1978, no Canadá, teve no Brasil o título "Vencendo a competição" (I 989), foi pioneira sobre os estudos dos jogos cooperativos e se tornou a referência em pesquisas acadêmicas brasileiras e livros específicos sobre o assunto. Sob sua inspiração foram elaborados os relevantes trabalhos, geralmente sob a forma de dissertações 
de mestrado na área da Educação Física, de Fabio Brotto (1999), Sérgio Abrahão (2004), Roberto Martini (2005), Fabrício Monteiro (2006), Marcilene Blanco (2007), e os livros de Brotto (1997, 200 I), Reinaldo Soler (2005) e Marcos Miranda Correia (2006). Apesar de existirem ações (pesquisas, projetos sociais, programa de pós-graduação) de repercussão bastante expressiva, o estudo dos jogos cooperativos como objeto de reflexão e investigação científica é muito recente e a produção de material teórico é limitada. Por isso, a proposta dos jogos cooperativos necessita ainda de estudos mais aprofundados, sobretudo, no que diz respeito a alguns de seus aspectos filosóficos, sociológicos e pedagógicos (CORREIA, 2006).

É possível afirmar que no cenário nacional a principal referência sobre os estudos dos jogos cooperativos é Fábio Brotto, ${ }^{4}$ com "Jogos cooperativos: se o importante é competir, o fundamental é cooperar ( 1997)" e "Jogos cooperativos: o jogo e o esporte como um exercício de convivência (200 I)". O autor, em linhas gerais, propõe a "repedagogização" do esporte pelo princípio dos jogos cooperativos, e ressalta as contribuições desse último no aprendizado esportivo de uma maneira diferenciada, baseado no encontro e não no confronto. Obviamente, não limita o princípio dos jogos cooperativos somente no âmbito do esporte, muito pelo contrário, a intenção é que esses jogos cheguem a outros espaços da vida social.

Brotto (1999) apresenta a visão de que grande parte dos jogos estimula o confronto e não o encontro entre os jogadores. Os jogos e os esportes competitivos estimulariam o confronto. $\bigcirc$ autor não parece levar em consideração teorias difundidas, como a de Norbert Elias, ${ }^{5}$ onde o esporte competitivo seria um força de substituição mimética do tipo de confronto que a guerra significa, como muitos jogos tradicionais, geralmente simulando a guerra. Esportes e jogos se caracterizariam pelas restrições à violência impostas pelo respeito obrigatório às regras que os estruturam. Para Elias (1992), o esporte moderno, controlado por regras e juízes, seria um vetor do processo civilizatório que diminui o umbral de aceitação da violência, gerando uma excitação socialmente aceitável. Ou seja, o esporte não elimina o confronto, apenas substitui uma forma violenta de confronto por uma violência que é controlada e diminuída. Ao invés de realizar a crítica de teorias difundidas, como a de Elias (1992), pois é uma alternativa interpretativa muito séria para seus argumentos, Brotto (1999) utiliza argumentos retóricos, sem apresentar evidências que o justifiquem no plano da análise histórica e social.

4. No Brasil, Brotto introduziu os jogos cooperativos e criou junto com sua esposa, Gisela Sartori Franco, em 1992, o Projeto cooperação - comunidade de serviços, dedicada à difusão dos Jogos Cooperativos e da ética da cooperação, por meio de oficinas, palestras, eventos, publicações e produção de materiais didáticos.

5. Ver Elias (1992). 
Em afirmação categórica, Brotto ( 1999 ) aponta que a competição proporciona situações capazes de eliminar a diversão e a alegria de jogar. Esta afirmação não parece corresponder com as declarações sobre os sentimentos dos esportistas e espectadores que, de modo geral e reiterado, afirmam a multiplicação do prazer no jogo e no esporte mediante a competição. Mais ainda, desconhece que o marketing esportivo fez da competição seu centro, por entender que maximiza a diversão e o prazer, refletindo-se na importância dada ao espetáculo esportivo sob a forma de competições na mídia. Então, não se compreende qual o fundamento para a competição proporcionar "situações" contrárias à diversão e ao prazer. Observe-se que pareceria que a força de sua argumentação está na palavra "situações". De fato, podem existir situações particulares que sejam entediantes e gerem desprazer. Se elas fossem majoritárias, talvez não tivéssemos nem esportistas, nem espectadores, nem marketing esportivo, nem competição esportiva, nem espetáculo esportivo.

objetivo da competição, segundo o autor, é eliminar os menos capazes e, consequentemente, produzir mais perdedores do que vencedores, pois, apenas um sai vencedor e os demais perdedores. Neste tipo de afirmação, recorrente no pensamento crítico do esporte, inverte-se a evidência dominante para a qual o objetivo da competição é proclamar os mais competentes, os vencedores que ganham os louros, as medalhas e os prêmios em espécie. São os mais competentes e vencedores que fazem a história do esporte e nela estão presentes. De fato, na lógica da competição os perdedores são eliminados e até esquecidos, porém seu objetivo não é produzir perdedores. Participar na competição é realizar uma "aposta" em si mesmo. Aposta de auto-superação e de hetero-superação, esta é uma afırmação tradicional dos analistas do esporte, dos jornalistas, dos esportistas e dos espectadores. Se assim não fosse, não poderíamos entender a participação na competição. Tudo indica que a excitação pela "aposta" gratificaria mais que sua perda. Caso contrário, não entenderíamos nem aos jogadores nem aos apostadores. Para "superar" estes lugares comuns seria necessário que argumentássemos com evidências que nos levem a um novo entendimento. Talvez a tarefa seja possível, porém ainda não foi realizada.

Algumas pesquisas acadêmicas sobre os jogos cooperativos como, por exemplo, em Monteiro (2006), Blanco (2007) e Pocera (2008), para citar algumas, têm criticado os jogos competitivos e, por sua vez, a competição, por acreditarem que os mesmos educam os indivíduos para os hábitos de individualidade, de rivalidade, de agressividade, além de fomentar a exclusão, a dominação e a inimizade. De novo aqui as teorias que enfatizam a geração dos valores contrários não são analisadas criticamente. As relações entre os termos críticos do esporte não são explicitadas. Assim, por exemplo, não se apresentam evidências para as relações 
entre individualidade e agressividade, entre individualidade e rivalidade, entre rivalidade e inimizade. De fato, para Elias (1992), mediante o esporte, e também mediante a política democrática, o inimigo se constitui como adversário, e o rodízio no poder e no pódio passa a ser visto como normal e desejado. Tais pesquisas acreditam que através dos seus princípios, os jogos cooperativos são capazes de reduzir ou eliminar o caráter agonístico dos jogos e, assim, construir uma sociedade com hábitos e costumes mais cooperativos e solidários. Observe-se que "reduzir" não é o mesmo que "eliminar". Aumentar a cooperação e solidariedade não é o mesmo que eliminar a competição. Reconhecer o papel estratégico do Estado no desenvolvimento inclusivo e sustentado, por exemplo, não significa eliminar o mercado e sua importância. Se a procura for um equilíbrio mais acentuado entre os dois princípios, deveríamos cuidar da linguagem e não usarmos termos como "eliminar", de fato, bastante agonístico e habitualmente empregado no sentido de fazer desaparecer o inimigo. Os defensores dos jogos cooperativos não deveriam estabelecer um desafio agonístico entre eles e os competitivos! Correríamos o pior dos riscos: maximizar o que desejamos "reduzir".

Segundo Brotto (1999, p. 75)

Os Jogos Cooperativos surgiram da preocupação com a excessiva valorização dada ao individualismo e à competição exacerbada, na sociedade moderna, mais especificamente, pela cultura ocidental. Considerada como um valor natural e normal da sociedade humana, a competição tem sido adotada uma regra em, praticamente, todos os setores da vida social.

Observe-se a ambiguidade do texto, sua força está nas palavras "excessiva" e "exacerbada". Se a valorização dada ao individualismo e à competição não fosse "excessiva", não necessitaríamos dos jogos cooperativos? Se a competição não fosse "exacerbada", não teríamos necessidade dos Jogos Cooperativos? De fato, ambas as palavras são qualificativos, implicando apenas nuanças da competição, e não são apresentadas evidências para os mesmos. Ambas as palavras são núcleos de lugares comuns na crítica à modernidade. De fato, vivemos com apreciações e avaliações contrapostas sobre ações e coisas da vida cotidiana. Muitas dessas contraposições são superadas recorrendo ao velho ditado: "sobre gosto não há nada escrito". Porém, quando queremos discutir a educação, deveríamos procurar fundamentos mais refinados e controlar o uso dos qualificativos, pois, parece existir o acordo de que há dimensões da educação que não podem ser tratadas apenas como "questões de gosto". Se tudo na educação fosse questão de gosto não demandaríamos propostas ou teorias orientadoras do "ato de educar".

Orlick (1989) partiu de uma preocupação semelhante para "justificar" o surgimento dos jogos cooperativos, pois, segundo o autor, sentia-se incomodado 
com o "excesso" de incentivo à competição, com o crescimento da violência, dos atos desumanos, da dificuldade de interação harmoniosa e, em especial, com o reflexo desse contexto na educação, agravada pelo perfil mais agressivo com que os jogos e os esportes vêm sendo desenvolvidos. Ele vê nos jogos cooperativos uma possibilidade de mudança a favor de um aprendizado cooperativo e solidário: "[ ... ] a simples reunião de pessoas socializadas competitivamente, em pequenos grupos, não é suficiente para melhorar a cooperação ou a amizade." (ORLICK, 1989, p. 123). Temos, o qual não significa um erro, um juízo moral sobre os descaminhos e declínio do mundo do esporte. Contudo, é paradoxalmente impactante que se multipliquem os programas alternativos de prática esportiva para controlar a vida na rua de crianças e jovens e, por esse caminho, diminuir a violência, os atos desumanos e os perigos que, no caso do Brasil, os dizimam. A ambiguidade do esporte competitivo parece aflorar na contraposição entre as declarações de Orlick (1989) e os programas de esporte "educativo", social ou ressocializador. A ambiguidade ressalta o exagero retórico usado a favor dos jogos cooperativos.

Outra preocupação demonstrada pela literatura dos jogos cooperativos diz respeito às atividades competitivas desenvolvidas prioritariamente nas aulas de Educação Física Escolar, que, por sua vez, teriam contribuído para a manutenção do sistema de organização social capitalista, uma vez que evidencia a seletividade, a dominação, a exploração, a hierarquização, e beneficiam os mais fortes, excluindo os menos aptos. De novo se outorga um poder conservador e reprodutor sem provas à educação. Em contrapartida, conforme acredita Moraes (2008, p. 18), "[...] os jogos cooperativos foram pensados como instrumentos de ludicidade, capazes de intervir no modelo capitalista de competição e promover uma revisão de valores e condutas na direção da cooperação." Agora a educação se enche de esperanças transformadoras. Veja-se o potencial da esperança: revisão de valores e condutas e na direção da cooperação. Os discursos a respeito da cooperação e suas vantagens sobre a competição são antigos e deram lugar a organizações e a políticas privadas ou públicas. A moderna administração de empresas, pelo menos desde a revolução na administração gerada por Taylor, ${ }^{6}$ adotou a cooperação como princípio a ser posto em prática para aumentar a produtividade e competitividade das empresas. A valorização da cooperação, então, pode estar a serviço daquilo que é criticado e rejeitado pelos defensores dos jogos cooperativos, que deveriam advertir suas proximidades com o discurso renovador da administração capitalista. Uma revisão da literatura sobre o entendimento do desenvolvimento inclusivo

6. Frederick Winslow Taylor ( 1856 - 1915) foi considerado o "Pai da Administração Científica" por propor a utilização de métodos científicos cartesianos na administração de empresas. 
mostraria seu lugar central nas estratégias formuladas, o que parece não se querer enfrentar, na reiteração da positividade da cooperação, e sua dificuldade de realização. Em contrapartida, apenas alguns fanáticos elaboram discurso a favor da competição e, reconheçamos, pareceria não precisar, pois ela se apresenta como "natural" (LOVISOLO, 2009).

A desconfiança de Brotto ( 1999 ) não é em relação ao potencial formador do jogo e do esporte, mas quanto aos valores atrelados a eles, atendendo a manutenção do modelo educacional dominante. A questão anterior a essa afirmação é: será que podem ser separados? Se esporte e valores atrelados agonísticos, competitivos e seletivos, entre outros, não são separáveis, então, ser contra o esporte e ser contra seus valores. Reconheçamos que um esporte não competitivo, não agonístico, não mereceria ser chamado de esporte.

É preocupado que os jogos não atendam a uma educação democrática, buscando a formação de um cidadão cooperativo e solidário, que Brotto ( 1999, p. 124) propõe, em seu estudo, "[... . o desenvolvimento de uma Pedagogia do Jogo e do Esporte, apoiada em estruturas socioeducacionais de cooperação e solidariedade."

As palavras "cooperativo" e "solidário" são ambíguas, deveriam ser especificadas, pois podem ser entendidas como mera adequação e aceitação, como perda da defesa do justo e dos próprios interesses. Nos jornais aparecem notícias sobre policiais que "cooperam" para realizar a justiça que eles desejam, pelas próprias mãos, ou que são "solidários" quando protegem a um colega que cometeu um delito. Ambas as palavras podem ser pragmaticamente usadas para justificar atos injustos. $\mathrm{Na}$ tradição de solidariedade e cooperação do anarquismo, os valores em questão são para adentro, isto é, para a comunidade ou classe. Como ser solidário e cooperativo com a classe capitalista, com os objetivos de dominação, com as distribuições injustas? Ou seja, postos em contextos específicos, os objetivos propostos por Brotto ( 1999 ) poderiam ter tantas interpretações contrastantes quanto seu inimigo: a competição exacerbada. Temos, então, como tarefa, refinar o entendimento que damos a essas palavras que parecem ser chaves ou tesouros de significados.

$\bigcirc$ jogo cooperativo tem sido referenciado como uma atividade educativa humanizadora porque, segundo Deacove (apud BROTTO, 1999, p. 76), "[...] são jogos com uma estrutura alternativa, onde os participantes jogam uns com os outros, ao invés de jogar uns contra os outros", diferentemente dos jogos tradicionais ou competitivos, em que os jogadores buscam a vitória a qualquer custo. Uma boa parte da humanidade entende que jogar uns contra outros, respeitando as regras, com fair play e lealdade, é altamente educativo, formativo. Não deveríamos expulsar, sem um trabalho crítico, essas crenças para fora de nossas elaborações, pois correríamos o risco de estar perdendo elementos potencialmente educativos. $\mathrm{Ou}$ 
será que estaríamos apenas no terreno das opiniões e das incertezas? Se assim o for, teríamos então que realizar tanto jogos cooperativos como competitivos para respeitar a diversidade de opiniões? Cada um deveria jogar aquilo que valoriza? Ou deveremos procurar um equilíbrio entre ambos, apoiados na virtude da prudência? Enfim, diversificar o investimento dado, que não sabemos os retornos que teremos no futuro? Respostas positivas significam escolher o caminho do meio. E isto parece adequado para tempos de incerteza.

Para Soler (2005), utilizando o Jogo Cooperativo haverá a diminuição dos problemas e dos conflitos. Pois, segundo ele, pode-se dizer

[...] sem medo de errar, que quanto maior for a parte da vida de uma criança envolvida com Jogos Cooperativos, mais ela aceitará a cooperação, e mais ainda estará disposta a cooperar tanto no jogo da escola quanto no grande jogo da vida. (SOLER, 2005, p. 48).

De novo estamos diante uma declaração geral e não específica. Problemas e conflitos formam parte significativa do jogo da vida. $O$ conflito foi e é visto como dinamizador das formas sociais (lutas de classes, sociologia do conflito, etc.). É bem possível que a cooperação seja um instrumento valioso para enfrentar problemas e conflitos, contudo, isso não significa que a tornemos um valor absoluto, um valor em si mesmo, a diminuição de problemas e conflitos. As grandes declarações devem ser mais bem formuladas e definidas para não fazer com que os jogos cooperativos, por exemplo, sejam apenas entendidos como ferramentas de controle e ajuste, isto é, como elemento central da dinâmica conservadora.

Brotto ( 1999) considera que através do desenvolvimento de uma Pedagogia do Jogo e do Esporte ou, como ele mesmo prefere propor, com a "repedagogização" do jogo e do esporte, que na verdade parece se aproximar mais de uma transformação didático-pedagógica, seria possível promover a inclusão de todos, assim como mais oportunidades de participação. Entre as características apontadas por Brotto (1999), direcionadas a essa transformação pelo princípio dos jogos cooperativos, destacam-se: responsabilizar-se por si mesmo e pelo bem estar dos outros; respeitar e recriar coletivamente as regras; descobrir e valorizar as diferentes formas de vencer; aprender "COM" o perder e o ganhar, ao invés de aprender "a" perder e "a" ganhar; harmonizar conflitos e superar crises; saber equilibrar a ansiedade. Observemos que os conteúdos propostos para a "repedagogização" seriam importantes para os esportes competitivos, na verdade a eles se aplicam e não aos jogos cooperativos. Temos na "repedagogização" um caminho do meio, uma forma de civilizar a competição e aprendermos com ela. Esta linha de importantes sugestões merece ser trabalhada, posta em prática, avaliada e reformulada. Contudo, suas relações com os jogos cooperativos não são claras. 
A retórica, desde seu surgimento entre os gregos e sua forte retomada pelos romanos, foi perseguida pelo anátema de ser um discurso dirigido a convencer ou influenciar um público, usando recursos não válidos sob o ponto de vista argumentativo e moral. Aristóteles (2005) comparou o manejo da retórica com o da espada (REBOUL, 2000). O direito de se defender devia levar todo homem a desenvolver a competência no uso de ambos os recursos. Na modernidade a retórica foi perdendo a centralidade que ocupou durante séculos no ensino (SKINNER, 1999). Nas últimas décadas, especialmente a partir da obra de Perelman (1993) e Perelman, Olbrechts-Tyteca, 2005), houve um ressurgimento considerável do interesse na retórica e de seu valor heurístico e argumentativo. Os autores reconhecem sua capacidade em gerar temas para as agendas de discussão e categorias que os estruturam (PLEBE; EMANUELE, 1992).

De modo geral, no entanto, os estudos concordam em aceitar o caráter agonístico da retórica. Sob sua inspiração os discursos são produzidos para convencer, para ganhar o debate. Ao invés de usar a longa tradição dos recursos retóricos em sentido de pesquisar as possibilidades, de expandir a indagação, usa-se para impor um ponto de vista e, não raro, a partir da reiteração abusiva de algumas afirmações frouxamente sustentadas. Este uso, talvez mau uso, não implica que as intenções sejam imorais ou inválidas. Talvez apenas signifique que o retórico auto, convencido do valor do que predica, usa recursos pouco válidos. Sob esta intencionalidade, suas categorias sofrem de falta de refinamento, seus argumentos, de articulação, e as evidências podem gerar dúvidas. Nesta direção geral estruturamos a crítica aos jogos cooperativos. Consideramos sua proposta valiosa e apenas sugerimos que suas categorias ou conceitos, seus argumentos e suas evidências merecem ser aprimorados. No campo da educação em geral e da educação física em particular, faz-se necessário e urgente abandonar a retórica no sentido referido, caminhar na recuperação da "boa retórica" que, talvez, seja a dialética.

Aristóteles (2005) considerava que a dialética se orientava de forma não agonística, em oposição à retórica, uma espada verbal que os homens deviam aprender a utilizar para se defenderem. Não se trata na dialética de ganhar um debate, mas de explorar criticamente as alternativas em oposição no tema, os pontos de vista contrários, as categorias que mutuamente se negam no embate do discurso retórico. De fato, isto talvez signifique, como é atribuído por exegetas de Aristóteles, a vontade de transitar pelo caminho do meio enquanto superação da luta agonística na oposição irredutível das categorias ou posições contrapostas. Convém então evitar a tendência de qualificar em termos de verdadeiro ou falso, de certo ou errado e, em muitos casos, de moral ou imoral. Devemos nos deslocar para o terreno 
do possível, do verossímil e das possíveis compatibilidades. Esta foi nossa intenção na leitura dos jogos cooperativos. Recusamos tanto o elogio à competição como certa ou verdadeira quanto seu anátema, e recusamos, ainda, aplicar os mesmos qualificativos aos jogos cooperativos.

Reconhecemos o valor positivo de expandir a prática dos jogos cooperativos enquanto não se os coloque como verdadeiros e únicos e em oposição, não dialética, eliminatória, da competição. Apostamos na tarefa de refinar as categorias, os argumentos e evidências em favor dos jogos cooperativos. Esta deveria ser uma tarefa da área da Educação Física a partir dos autores que realizaram os valiosos esforços pioneiros. Agradecemos a eles pela abertura de um caminho importante cuja tradição não é nem pequena nem pouco significativa. Acreditamos que uma boa "repedagogização", como Brotto (1999) propõe, deveria ser dialética e recuperar o trabalho formativo, tanto com a cooperação quanto com a competição. Precisamos, além da elaboração dialética, a realização de experiências que nos permitam pensar a "repedagogização" com recursos práticos do processo de ensino aprendizagem.

\section{Competition and Cooperation: Searching for a Balance}

ABSTRACT: The paper analyzes the content of the messages that sees the purposes of the cooperative games as superior to the competitive games, especially when a transforming education regarding the human social values is proposed. To do so, the main ideas of the authors who have been dedicating themselves to the study of cooperative games were analyzed. In general, the arguments used stand out the values of cooperation to the detriment of competition, making responsible the competitive games upon the dissemination of non educative values. As result, there are rhetorical statements, no evidences or consistent theoretical proofs, a forced attempt of authors to legitimate the cooperative games in the expected education and to show its advantage on the competitive games.

KEYWORDS: Rhetoric; cooperative games; competitive games.

\section{Competición y Cooperación: Búsqueda del Equilibrio}

RESUMEN: El artículo analiza el contenido de mensajes que coloca la propuesta de los juegos cooperativos como superior a los competitivos, especialmente cuando se propone una educación transformadora en relación a valores sociales humanos. Para eso, se analizaron las principales ideas de autores que se han dedicado al estudio de los juegos cooperativos. De una forma general, los argumentos utilizados enfatizan los valores de cooperación en perjuicio de la competición, responsabilizando a los juegos competitivos por la diseminación de contra valores educativos. Como resultado, hay afirmaciones retóricas, sin evidencias o fundamentos teóricos consistentes, un intento forzado de autores de legitimar los juegos cooperativos en la educación pretendida y de mostrar su ventaja sobre los competitivos.

PALABRAS CLAVES: Retórica; juegos cooperativos, juegos competitivos. 


\section{REFERÊNCIAS}

ARISTÓTELES. Retórica. Lisboa: Centro de Filosofia da Universidade de Lisboa, 2005.

BLANCO, M. R. Jogos cooperativos e educação infantil: limites e possibilidades. I 8 I f. Dissertação (Mestrado em Educação) - Universidade de São Paulo, São Paulo, 2007.

BROTTO, F. O. Jogos cooperativos: o jogo e o esporte como um exercício de convivência. 1999. 209 f. Dissertação (Mestrado em Educação Física)- Faculdade de Educação Física, Universidade Estadual de Campinas, Campinas, 1999.

CHARLOT, B. Relação com o saber, formação de professores e globalização: questões para a educação hoje. Porto Alegre: Artmed, 2005.

CORREIA, M. M. Trabalhando com jogos cooperativos: em busca de novos paradigmas na Educação Física. Campinas: Papirus, 2006.

DAWKINS, R. O gene egoísta. São Paulo: Cia das Letras, 2007.

ELIAS, N.; DUNNING, E. A busca da excitação. Lisboa: Difelm, 1992.

LOVISOLO, H. Competição, cooperação e regulações. In: .; STIGGER, M. Esporte de rendimento e esporte na escola. Campinas: Autores associados, 2009. p. 2 I I-2 17. MONTEIRO, F. Transformação das aulas de educação física: uma intervenção através dos jogos cooperativos. 222 f. Dissertação (Mestrado em Educação Física) - Faculdade de Educação Física, Universidade Estadual de Campinas, Campinas, 2006.

MORAES, V. L. Os jogos cooperativos nas ações do Programa a União Faz a Vida, na região do médio Alto Urugaui - RS. 2008. 101 f. Dissertação (Mestrado em Educação) - Universidade do Vale do Rio dos Sinos, São Leopoldo, 2008.

ORLICK, T. Vencendo a competição. São Paulo: Círculo do Livro, 1989.

PERELMAN, C.; OLBRECHTS-TYTECA, L. Tratado de argumentação/a nova retórica. São Paulo: Martins Fontes, 2005.

PERELMAN, C. O império retórico. Porto: ASA, 1993.

PLEBE, A.; EMANUELE, P. Manual de retórica. São Paulo: Martins Fontes, 1992.

POCERA, J. A. (2008). Análise das relações desencadeadas pelos jogos cooperativos na Educação Física do Colégio Agrícola Senador Carlos Gomes de Oliveira. 2008. 94 f. Dissertação (Mestrado em Educação Agrícola) - Universidade Federal Rural do Rio de Janeiro, Seropédica, 2008. REBOUL, O. Introdução á retórica. São Paulo: Martins Fontes, 2000. 
SEN, A. Desenvolvimento como liberdade. São Paulo: Cia das Letras, 2000.

SOLER, R. Jogos cooperativos. Rio de Janeiro: Sprint, 2005.

SKINNER, Q. Razão e retórica na filosofia de Hobbes. São Paulo: Ed da Unesp: Cambrige, 1999.

Recebido em: 13 set. 2010 Aprovado em: 2 maio 201 I

Endereço para correspondência: Igor Barbarioli Muniz Rua Ludwik Macal, 809, ap. 102 Jardim da Penha Vitória-ES CEP: 29060-030 